\title{
Developing the formula for state subsidies for health care in Finland
}

\author{
Unto Häkkinen and Jutta Järvelin \\ Centre for Health Economics - Stakes (CHESS), Finland
}

Scand J Public Health 2004; 32: 30-39

\begin{abstract}
Aim: The aim was to generate a research-based proposal for a new subsidy formula for municipal healthcare services in Finland. Methods: Small-area data on potential need variables, supply of and access to services, and age-, sex- and casemix-standardised service utilisation per capita were used. Utilisation was regressed in order to identify need variables and the cost weights for the selected need variables were subsequently derived using various multilevel models and structural equation methods. Results: The variables selected for the subsidy formula were as follows: age- and sex-standardised mortality (age under 65 years) and income for outpatient primary health services; age- and sex-standardised mortality (all ages) and index of overcrowded housing for elderly care and long-term inpatient care; index of disability pensions for those aged 15-55 years and migration for specialised non-psychiatric care; and index of living alone and income for psychiatric care. Conclusion: Decisions on the amount of state subsidies can be divided into three stages, of which the first two are mainly political and the third is based on the results of this study.
\end{abstract}

Key words: healthcare, regional allocation, small-area research, state subsidies.

Unto Häkkinen, Centre for Health Economics - Stakes (CHESS), PO Box 220, Lintulahdenkuja 4, 00530 Helsinki, Finland. Email: unto.hakkinen@stakes.fi

\section{BACKGROUND}

Nowadays, healthcare resources in many countries are allocated and/or risk adjusted using variables describing both community- and individual-level characteristics of the population. In practice, many risk adjustment or capitation formulae are used; they are usually applied to different services at various hierarchical levels of healthcare provision using a variety of financial methods (1).

In the Nordic countries local government (at municipal or county level) is responsible for organising the majority of healthcare services. Central government supports local healthcare provision with financial grants, the principle objective being to enable local communities to deliver "standard" healthcare whilst they raise extra funds by levying a local tax (1).

The aim of this paper was to develop a formula for allocating state subsides for municipal health services and the care of the elderly in Finland. Here, a specific capitation formula is applied on a regional basis. Besides the Nordic countries, such formulae are used in tax-based healthcare systems such as in the United Kingdom, Australia, and Canada. The Finnish approach differs in that here the capitation is applied to a whole range of services, whereas in many other countries it is applied to more specific services. This means that the development of a regional formula also includes political decisions about priorities between different health services. In this study we have tried to separate the regional resource allocation process into stages, two of these being mainly political and one stage using the ("technical") results of our empirical study.

\section{APPROACHES TO DESIGNING A FORMULA}

The development of resource allocation formulae has generally been based either on normative judgements or on empirical approaches (2). Using the latter, available data are used to determine an association between healthcare utilisation (or health expenditure) and selected need indicators. Normative judgements, by contrast, are based on views of what ought to be fair distribution of resources. These may employ epidemiological or other scientific evidence.

Formulae proposed by empirical evidence have almost always been changed by the political decisionmaking process, at least to some extent. This has happened in England several times, for instance, and 
in Finland in 1996. As a result, the existing allocation formulae are often a mixture of empirical approaches and political judgements.

In England the historical development of the resource allocation formula demonstrates a continuous tension between normative and empirical solutions. The old RAWP formula from the 1970s was normatively justified, whereas since 1988 the balance has shifted more towards an empirical approach. Judgements and assumptions about the nature of need have still to be made in order to construct a usable formula as empirical data on what exists cannot provide a complete guide to what ought to be a fair distribution of resources (2).

The empirical approach assumes that existing utilisation reflects the need for healthcare. There are, however, several issues that need to be addressed at this point. One is the importance of controlling for factors that are not related to need. These are factors related to supply, local policy choices, accounting methods, or similar factors. If past utilisation as such were the basis for allocating resources, it would give an incentive to provide more care than necessary, or for providers to distort diagnoses towards more expensive ones. Therefore, if utilisation is to be used as a measure in the design of a formula, those variations in utilisation that are caused by illegitimate needs have to be determined and eliminated. The empirical approach is widely used in many countries, such as England (3-6), Scotland (7), Australia (8), Sweden (9, 10), and Finland (11).

\section{FINNISH STATE SUBSIDY SYSTEM FOR HEALTHCARE}

In its institutional structure, financing, and goals, the Finnish healthcare system is closest to those in other Nordic countries and the UK, in that it covers the whole population and its services are mainly produced by the public sector and financed through general taxation. Finland's 448 municipalities (local government authorities) are responsible for providing health services.

The municipalities are legally obliged to provide health services for their residents. These are financed by municipal taxes, state subsidies, and user charges. Municipally provided services include primary and specialist healthcare and social services (e.g. elderly care, child daycare and social assistance). Primary healthcare mainly takes place in health centres, which are owned by municipalities or federations of municipalities. Preventive care for communicable and non-communicable diseases, ambulatory, medical, and dental care, an increasing number of outpatient specialised services, and various public health programmes (e.g. maternity and school care) are provided by the health centres. They are also responsible for occupational health services (e.g. for farmers), and for services for specific patient groups, e.g. diabetes and hypertension clinics. Specialist care (psychiatric and acute non-psychiatric) is provided by 20 hospital districts, which are federations of municipalities. Each municipality must be a member of a hospital district. In addition to services provided through health centres or hospital districts municipalities may purchase them from a private provider.

State (central government) subsidies for healthcare (to municipalities) are fixed annually by parliament. State subsidies for running costs of municipal health services are given as non-earmarked lump sum grants, which are calculated prospectively using a specific capitation formula. Subsidies are paid automatically to the municipalities without the need to apply for them. They are calculated according to certain criteria; during 1993-96 these included population, age structure, mortality (SMR for all ages), population density, land area, and the financial capacity of the municipality. The archipelago municipalities received a somewhat higher subsidy. The relevance of these criteria has been examined, and new criteria were developed in our earlier study (11). Based partly on our findings new criteria were adopted from the beginning of 1997 . These included population, age structure and age-standardised index of invalidity pensions for those under 55 years.

\section{AIMS}

The purpose of the present study was to further develop the criteria for state subsidies. State subsidies in Finland have two functions: first, to give municipalities enough resources (in addition to municipal tax revenues) to provide some standard level of care; second, to divide the resources available to municipalities according to need for services. In this study we concentrate on the latter function, as the first is assumed to be determined by the political process.

\section{STARTING POINTS OF THE STUDY}

A good formula should take into account at least three aspects $(11,12)$ : efficiency, equity, and data availability. First, a good formula should give incentives for efficiency by promoting awareness of the costs and benefits of health services among municipalities and other parties concerned. The formula should therefore be resistant to manipulation and avoid perverse incentives. For example, it should not give any incentives to "overprovide" care or discourage municipalities from remedying the causes 
of ill health; an example of the latter would be to include disability pensions (if number of persons on disability pension is used as a criteria).

Second, a formula must ensure that each municipality has an equal opportunity to allocate more resources to servicing population areas with greater needs and less to areas with smaller needs.

In practice the third criterion is the most restrictive: the formula should be financially and administratively feasible. Data should be easily available, up to date and available each year. The formula should also be relatively simple, transparent, and credible with regard to the relationship between level of funding and level of need.

A resource allocation formula cannot by itself guarantee, however, that resources are used in a costefficient or equitable way at the local level. In Finland, the municipalities (representing the local population) have the role of deciding how to allocate resources to healthcare and how to divide them between specific health services. Although only about $24 \%$ of municipal healthcare expenditure is financed by state subsidies, its significance in practice may be augmented in two ways. First, its impact is much greater than $24 \%$ for many small, low-income municipalities with high relative need for services. Second, the formula can be used as a means of indicating government priorities in municipal healthcare. Although the municipalities do not have to follow the national guidelines in resource allocation, they often request these as a starting point for local decision making. In addition, large cities apply the need criteria developed for state subsidies (11) in their own sub-area healthcare resource allocation.

In the present study the following three principles were used in deriving the formula:

1. Services were divided into six groups (Table I) according to the availability of data on cost and utilisation and on the type of need. Specific need criteria were derived for each service group. The purpose of the study was to develop a servicespecific formula, but not to give cost (priority) weights for the different service groups. This was considered the responsibility of policy makers (the ministry, government, and parliament).

2. Need criteria were developed for various service groups using different approaches. For some services (primary care, care of the elderly and long-term hospital care, specialised non-psychiatric care, and psychiatric care) the criteria were developed using an econometric study. For other, relatively minor, groups the suitable criteria were assumed to be solely municipal population size (for environmental healthcare) or, in addition, age and sex structure (other primary care services).

3. The starting point in the econometric studies was that age and sex structure were the basic factors. The objective was to discover what additional factors would serve as suitable need criteria. The age- and sex-specific cost weights were first calculated from national statistics, registers, and

Table I. Service groups and approaches used in the study

\begin{tabular}{|c|c|c|c|}
\hline Service group & $\begin{array}{l}\text { Share of total } \\
\text { expenditure } \%\end{array}$ & Need criteria & $\begin{array}{l}\text { Dependent variable in } \\
\text { econometric study }\end{array}$ \\
\hline Environmental health services & 2 & Population & - \\
\hline $\begin{array}{l}\text { Primary outpatient healthcare } \\
\text { (visits to a GP and nurse) }\end{array}$ & 13 & $\begin{array}{l}\text { Population, age, sex, } \\
\text { and other potential } \\
\text { need variables }\end{array}$ & $\begin{array}{l}\text { Age- and sex-standardised per capita } \\
\text { visit to a doctor and a nurse (weighted } \\
\text { by national average unit costs of the } \\
\text { two type of visits) }\end{array}$ \\
\hline $\begin{array}{l}\text { Other primary care (e.g. preventive } \\
\text { care, dental care, and occupational } \\
\text { care produced in health centres) }\end{array}$ & 5 & $\begin{array}{l}\text { Population, age and } \\
\text { sex }\end{array}$ & - \\
\hline $\begin{array}{l}\text { Care of the elderly and long-term } \\
\text { hospital care }\end{array}$ & 28 & $\begin{array}{l}\text { Population, age, sex } \\
\text { and other potential } \\
\text { need variables }\end{array}$ & $\begin{array}{l}\text { Age- and sex-standardised per capita } \\
\text { use of services for the elderly and } \\
\text { long-term hospital care (weighted by } \\
\text { national average unit costs of the } \\
\text { services) }\end{array}$ \\
\hline Specialised non-psychiatric care & 42 & $\begin{array}{l}\text { Population, age, sex } \\
\text { and other potential } \\
\text { need variables }\end{array}$ & $\begin{array}{l}\text { Age- and sex-standardised per capita } \\
\text { admissions and outpatient visits in } \\
\text { somatic care (weighted by national } \\
\text { DRG weights and cost weights for } \\
\text { outpatient visits) }\end{array}$ \\
\hline Psychiatric care & 10 & $\begin{array}{l}\text { Population, age sex, } \\
\text { and other potential } \\
\text { need variables }\end{array}$ & $\begin{array}{l}\text { Age- and sex-standardised per capita } \\
\text { hospital days and outpatient visits in } \\
\text { psychiatric care (weighted by national } \\
\text { average cost of the two outputs) }\end{array}$ \\
\hline
\end{tabular}




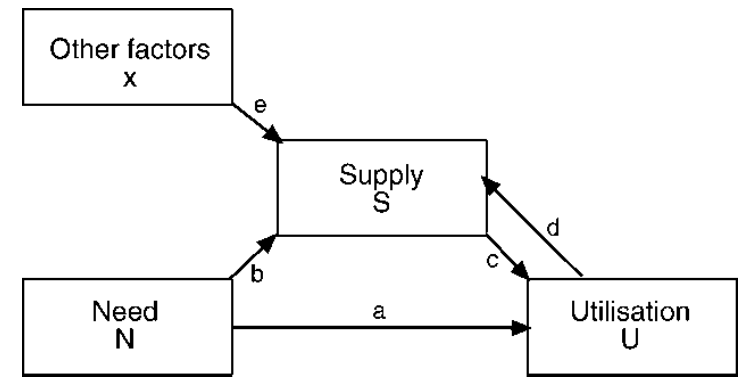

Fig. 1.

studies. In the econometric models, the dependent variable was age- and sex-standardised utilisation.

The aim was to develop criteria only for need factors, although the state subsidy should also take into account the excess cost due to rurality and remoteness of a municipality. The excess cost can be assumed to affect the unit cost of providing services but not the need for them. This has been considered in a separate study (13).

\section{MODEL USED IN THE ECONOMETRIC STUDIES}

The idea behind the empirical studies is that current utilisation is assumed to reflect the need for services after controlling for the effect of supply of services. We applied a simple model (Figure 1) in which utilisation $(U)$ is a function of need $(N)$ and supply and availability $(\mathrm{S})$ of services $(4,6,7)$ :

$$
U_{\mathrm{i}}=\mathrm{f}_{1}(N, S)
$$

The supply of services is not necessarily unrelated to utilisation and we can assume that it depends on former utilisation, need for services and other factors $(X)$. If utilisation of services affects supply (arrowed in Figure 1) it is endogenous. In this case supply is a function of utilisation, need and other factors:

$$
S_{\mathrm{i}}=\mathrm{f}_{2}(U, N, X)
$$

The endogeneity of supply complicates statistical strategy. In this case we used a two-stage estimation, in which we first estimated the supply function $\left(S_{\mathrm{i}}=\mathrm{f}_{3}(N, X)\right.$ and the predicted value of supply from that function was used in the estimation of the utilisation function (1).

\section{DATA, VARIABLES AND STATISTICAL METHODS}

The statistical analysis was based on cross-sectional data from 1998. We had data at the municipal level for all variables. However, as the population size of municipalities varies from 200 to over 500000 , the data from the smallest were aggregated by combining them with their neighbouring municipalities into larger units (about 10000 persons). Most of the statistical testing and specification of the models was based on these aggregated data (Sample 1, $n=197$ ) as information on all variables were included.

Finland's six largest cities (municipalities) are home to about 1.4 million people, i.e. about $30 \%$ of the total population. To make the data more representative of urban characteristics, sub-area data from the six largest cities were gathered. This enabled us to increase the number of observations to 254 (Sample 2 ), although the sub-area data did not include all variables.

\section{Variables}

The dependent variables were age- and sex-standardised utilisation weighted by average unit cost of services (Table I). The average unit cost for the whole country was used because the quite large differences in productivity (14-16) were not allowed to affect the formula. The potential need and availability (supply) variables are described in Table II. Accessibility of acute hospital care and psychiatric care was measured in a similar way to the British small area studies $(4,7)$ and used the idea of spatial modelling. A distanceweighted personnel per capita was calculated using the number of wage-weighted personnel per $10 \quad 000$ inhabitants in the hospital district and the distance from the centre of a municipality to the nearest hospital.

\section{Statistical strategy}

The statistical analysis was done in two parts. The aim of the first part was to choose need variables. In the second part we searched for the appropriate cost weights for the chosen need variables.

In the first part of the statistical analysis we started our statistical analysis by estimating the supply functions using potential need variables and some other regional $(X)$ variables. The latter were included in order to guarantee the identification of the models. As $X$ variables we used population density, proportion of persons over 65 of the total population, and total population.

The endogeneity of supply was tested with the normal procedure by adding predictions from supply functions to the utilisation function (17). If supply was indicated to be endogenous, a two-stage strategy was applied. The search for need variables was based on statistical significance and value and sign of coefficients. In addition, the functional form (linear versus 
Table II. Potential need and availability variables used in the study

Potential need variables $(\mathrm{N})$ :

Different mortality indices (SMR for $0-65,0-75$, and all ages, life expectancy for persons over 65)

Age- and sex-standardised index of disability pensions for ages $15-55$

The proportion of low weight births $(<2500 \mathrm{~g})$ of all bights

Index of migration ((net migration + population)/population), four-year average

The proportion living alone of total population and of those over aged +65

Housing conditions (proportion in households in overcrowded or poor condition accommodation)

Education (proportion of at least middle level of education of total $(+15)$ population, proportion of upper level of education of total $(+15)$ population)

Average disposable income per household unit ( 1 adults, 0.5 children)

Income distribution (gini coefficient of disposable income)

Industrial structure (proportion of workforce in agriculture, manufacturing, contracting, trade, and transport industries of total workforce)

Unemployment (unemployment rate and relative share of long-term unemployment) One-parent families share of all families and families with children

Supply and availability variables (S):

Availability of specialist non-psychiatric care (total number of wage-weighted personnel working in non-psychiatric specialist care in hospital district/10 000 inhabitants)/(square from municipality to nearest somatic hospital (kilometres))

Availability of psychiatric care (total number of wage weighted personnel working in psychiatric care in hospital distict/10 000 inhabitants)/(square from municipality to nearest psychiatric hospital (kilometres))

Primary healthcare personnel: number of wage-weighted personnel (doctors and nurses) working in primary health care/10 000 inhabitants

Personnel in care of the elderly: number of wage-weighted personnel in care of the elderly and long-term hospital care/10 000 inhabitants

log-linear using the $P_{\mathrm{E}}$ test (18)) and specification (RESET and $\mathrm{J}$ tests $(17,19)$ ) of the models were evaluated. After testing numerous specifications iteratively, the final models were obtained that were sound both statistically and intuitively.

Most of the statistical modelling and testing were made using the aggregate data (Sample 1) as this included all variables. However, the chosen need variables should also be significant when the models are estimated from the more disaggregated data (Sample 2).

The coefficients of the chosen need variables in the first part cannot be used as cost weights as such for two reasons. First, the analysis in the first part was made using the assumption of independently distributed residuals. It can be assumed that in our case this assumption was violated because a hospital district as a monopolistic producer provides most of its specialist services to the population of the municipalities within its area. This holds particularly for non-psychiatric specialist care and psychiatric care, but can also have an effect on primary care and care for the elderly. This problem can be handled with a multilevel model with random effect (20). In this case the specification can be evaluated using the Lagrange multiplier test (18). A fixed effect model (identical to the use of regional dummy variables) can also be considered. The choice of specification (fixed versus random effects) can be informed by the Hausman test (21).

Second, the coefficients of the first part describe only the direct effect of a need variable (arrow "a" in Figure 1) on utilisation. One should additionally take into account the possible indirect effect (via supply) of the chosen need variable on utilisation. The indirect effect of the need variable was considered in two ways. In the case of an endogenous supply variable a structural model was estimated using the LISREL approach (22). In the case of an exogenous supply variable the system of equations can be assumed to be recursive and the indirect effect can be evaluated using the coefficients of the need variables in the supply function. The indirect effects could be evaluated only using the most aggregated data (Sample 1).

\section{RESULTS}

Table III describes the results of the first part for the four explanatory variables. In addition to selected need variables the models include only the statistically significant supply variables. The table reports the final models estimated from Samples 1 and 2. For all four dependent variables the $P_{\mathrm{E}}$ tests recommended log linear rather than linear specification. Only in the model describing the care of the elderly and long-term hospital care does the $P_{\mathrm{E}}$ test not unambiguously favour the log linear model. However, in this case both the RESET and $\mathrm{J}$ test indicated misspecification for the linear model.

In addition, supply tended to be endogenous only in the model describing specialised non-psychiatric care, although also in this case the only endogenous supply variable was not significant when the model was estimated from Sample 2.

On the basis of the results the variables selected for 
Table III. Final models from first part of the statistical analysis

\begin{tabular}{|c|c|c|c|c|c|c|c|c|}
\hline \multirow{2}{*}{$\begin{array}{l}\text { Dependent variables } \\
\text { Sample/model }\end{array}$} & \multicolumn{2}{|c|}{$\begin{array}{l}\text { Primary outpatient } \\
\text { healthcare }\end{array}$} & \multicolumn{2}{|c|}{$\begin{array}{l}\text { Care of the elderly and } \\
\text { long-term hospital care }\end{array}$} & \multicolumn{2}{|c|}{$\begin{array}{l}\text { Specialised non- } \\
\text { psychiatric care }\end{array}$} & \multicolumn{2}{|l|}{ Psychiatric care } \\
\hline & Sample 1/P1 & Sample 2/P2 & Sample 1/E1 & Sample 2/E2 & Sample 1/S1 & Sample 2/S2 & Sample 1/PS1 & Sample 2/PS2 \\
\hline Functional form & Log-linear & Log-linear & Log-linear & Log-linear & Log-linear & Log-linear & Log-linear & Log-linear \\
\hline Constant & $5.40 * * *$ & $6.63 * * *$ & 0.99 & $1.10^{*}$ & $3.55^{* * *}$ & $3.56^{* * *}$ & $7.7 * * *$ & $5.8^{* * *}$ \\
\hline \multicolumn{9}{|l|}{ Need variables } \\
\hline $\begin{array}{l}\text { Age- and sex-standardised mortality } \\
\qquad(0-65, \text { SMR65) }\end{array}$ & $0.15 * * *$ & $0.10^{*}$ & & & & & & \\
\hline $\begin{array}{l}\text { Age- and sex-standardised mortality } \\
\text { (all ages, SMR) }\end{array}$ & & & $0.51 * * *$ & $0.50^{* *}$ & & & & \\
\hline $\begin{array}{l}\text { Age- and sex-standardised index of } \\
\text { disability pensions for ages } \\
15-55 \text { (DISAB) }\end{array}$ & & & & & $0.38 * * *$ & $0.27 * * *$ & & \\
\hline Index of migration (MIG) & & & & & $-3.95^{*}$ & $-4.61^{* * *}$ & & \\
\hline $\begin{array}{l}\text { Proportion of population living } \\
\text { alone (ALONE) }\end{array}$ & & & & & & & $0.59 * * *$ & $0.54 * * *$ \\
\hline $\begin{array}{l}\text { Proportion of households living in } \\
\text { overcrowded accommodation } \\
\text { (CROWDED) }\end{array}$ & & & $0.46^{* * *}$ & $0.44 * * *$ & & & & \\
\hline $\begin{array}{l}\text { Average disposable income per } \\
\text { household unit (INC) }\end{array}$ & $-0.44 * * *$ & $-0.71 * * *$ & & & & & $-1.17 * * *$ & $-0.67 * * *$ \\
\hline \multicolumn{9}{|l|}{ Supply and availability variables (S) } \\
\hline $\begin{array}{l}\text { Availability of specialist } \\
\text { non-psychiatric care }\end{array}$ & - & & & & $0.028^{*}$ & $0.014^{*}$ & & \\
\hline Availability of psychiatric care & - & & & & $-0.027 * *$ & & $0.11 * * *$ & $0.09 * * *$ \\
\hline $\begin{array}{l}\text { Primary healthcare } \\
\text { personnel/population }\end{array}$ & $0.51 * * *$ & $0.62 * * *$ & & & & $-0.054^{*}$ & & \\
\hline $\begin{array}{l}\text { Personnel in care of the } \\
\text { elderly/population }\end{array}$ & $0.47 * * *$ & $-0.57^{* * *}$ & & & $-0.275^{* * * \#}$ & & & \\
\hline \multicolumn{9}{|l|}{ Statistical tests } \\
\hline Reset & 0.260 & & 0.132 & & 0.093 & & 0.727 & \\
\hline $\mathbf{J}$ test & - & & & & 0.055 & & & \\
\hline$P_{\mathrm{E}}$ test & 0.023 & & 0.404 & & 0.002 & & 0.001 & \\
\hline$P_{\mathrm{E}}$ test, other form & 0.839 & & 0.559 & & 0.744 & & 0.543 & \\
\hline Adj.J $R^{2}$ & 0.35 & 0.60 & 0.25 & 0.24 & 0.43 & 0.40 & 0.24 & 0.27 \\
\hline
\end{tabular}


the subsidy formula were as follows: age- and sexstandardised mortality (age under 65 years) and income for outpatient primary health services; ageand sex-standardised mortality (all ages) and index of overcrowded housing for elderly care and long-term inpatient care; index of disability pensions for those aged 15-55 years and migration for specialised nonpsychiatric care; and index of living alone and income for psychiatric care.

The value coefficients of the selected need variables changed somewhat when models were estimated from more disaggregated data (Sample 2). For example, income elasticity changed from -0.44 to -0.71 in the model for outpatient primary healthcare. The opposite occurred in psychiatric care, where income elasticity changed from -1.17 to -0.67 . In addition, there was a small change in coefficients when hospital district effect was included in the models. In this case the most notable change was the decrease in the elasticity of the disability index (about 0.1) in the model explaining use of specialist non-psychiatric care.

In the second part of the statistical analysis, where the aim was to derive cost weights for chosen need variables, we estimated the models using multilevel analysis from both samples. As stated earlier, we did not perform statistical modelling and tests on the more disaggregated data because of missing data and also because the modelling and tests are more complicated in multilevel analysis. However, multilevel estimations from both samples gave very similar coefficients. We ended up recommending the cost weights derived from Sample 2 and presented in Table IV because we regarded Sample 2 to better reflect the urban characteristics associated with big cities.

In most cases the fixed and random effect models gave rather similar coefficients for selected need variables (Table IV). We finally chose to recommend the use of coefficients from the random effect model, which was also verified by the Hausman test.

The direct and indirect effects of the need variables were also calculated using the LISREL approach from the model describing the use of specialist nonpsychiatric care, which was the only case where an endogenous supply variable was observed. The indirect effect of the two selected need variables via supply was very small. In addition, differences between direct effects were rather small when estimated using different (OLS, Random effect, Fixed effect, Structural model using LISREL) statistical approaches.

In the case of the other three dependent variables, only for psychiatric care did the estimated supply functions indicate a significant indirect effect of the selected need variables. In this case income was positively related to the availability of psychiatric care. Estimated from Sample 1 the coefficient of income in the supply equation was 3 , which means that the indirect effect was 0.3 . Thus the total effect (elasticity) of income would be -0.87 compared with the direct effect of -1.17 (Table III model PS1). In the earlier studies on regional resource allocation the indirect effects were treated in different ways $(4,7)$. In this study we did not take this indirect effect into account, because the positive effect of income on the supply of psychiatric care was regarded as not legitimate for equity reasons. As we recommend the use of the results of the random effect model from Sample 2, the income elasticity is still lower $(-0.58)$ in absolute terms than the total effect estimated from Sample 1.

\section{THE FINAL FORMULA}

Based on the results derived from the random effect model using Sample 2 (Table IV) we can calculate a relative need indicator for each group of the services. The need indicators for outpatient primary healthcare (NOPH), other primary care in health centres (NOTHER), care of the elderly and long-standing hospital care (NELD), specialised non-psychiatric care (NSPE) and psychiatric care (NPSY) in area (municipality) a were:

$$
\begin{aligned}
& \mathrm{NOPH}_{\mathrm{a}}=\mathrm{R}_{\text {oph a }} \mathrm{SMR}_{\mathrm{a}} 5_{\mathrm{a}}^{0.10} \mathrm{INC}_{\mathrm{a}}^{-0.73} \\
& \text { NOTHER }_{\mathrm{a}}=\mathrm{R}_{\text {other a }} \\
& \mathrm{NELD}_{\mathrm{a}}=\mathrm{R}_{\text {eld }} \mathrm{SMR}_{\mathrm{a}}^{0.48} \mathrm{CROWDED}_{\mathrm{a}}^{0.38} \\
& \mathrm{NSPE}_{\mathrm{a}}=\mathrm{R}_{\text {spe a }} \operatorname{DISAB}_{\mathrm{a}}^{0.18} \mathrm{MIG}_{\mathrm{a}}^{-5.90} \\
& \mathrm{NPSY}_{\mathrm{a}}=\mathrm{R}_{\text {psy a }} \mathrm{ALONE}_{\mathrm{a}}^{0.53} \mathrm{INC}_{\mathrm{a}}^{-0.59}
\end{aligned}
$$

where $R_{\text {oph a }}, R_{\text {other a }}, R_{\text {eld a }}, R_{\text {spe a }}, R_{\text {psy a }}$ are the age- and sex-standardised risk populations in area (municipality) a. The weighted risk population is calculated using the cost weights: $R_{a}=\sum_{i} C_{i} V_{i a}$, where $C_{i}$ is cost weight for age and sex groups and $\mathrm{V}_{\text {ia }}$ is the share of the age (i) and sex (s) groups of the total population in area (municipality) a

SMR $65_{\mathrm{a}}$ is the age- and sex-standardised mortality index $(+65)$ in area a

$\mathrm{INC}_{\mathrm{a}}$ is the average disposable income per household in area a

$\mathrm{SMR}_{\mathrm{a}}$ is the age- and sex-standardised mortality index (all ages) in area a

CROWDED $_{\mathrm{a}}$ is the proportion of households living in overcrowded accommodation in area a

DISAB $_{a}$ is the age- and sex-standardised index of disability pensions for ages $15-55$ in area a

$\mathrm{MIG}_{\mathrm{a}}$ is the index of net migration in area a

$\mathrm{ALONE}_{\mathrm{a}}$ is the proportion of the total population living alone in area a

By multiplying the areas' need indices with a constant (calculated from whole-country data) we 
Table IV. Estimation results from fixed and random effect models ${ }^{\mathrm{a}}$

\begin{tabular}{|c|c|c|c|c|c|c|c|c|}
\hline \multirow{2}{*}{$\begin{array}{l}\text { Dependent variables } \\
\text { Sample/model }\end{array}$} & \multicolumn{2}{|c|}{$\begin{array}{l}\text { Primary outpatient } \\
\text { healthcare }\end{array}$} & \multicolumn{2}{|c|}{$\begin{array}{l}\text { Care of the elderly and } \\
\text { long-term hospital care }\end{array}$} & \multicolumn{2}{|c|}{ Specialist non-psychiatric care } & \multicolumn{2}{|l|}{ Psychiatric care } \\
\hline & Sample $2 / \mathrm{P} 2$ & Sample $2 / \mathrm{P} 2$ & Sample 2/E2 & Sample 2/E2 & Sample 2/S2 & Sample $2 / \mathrm{S} 2$ & Sample 2/PS2 & Sample 2/PS2 \\
\hline Functional form & Log-linear & Log-linear & Log-linear & Log-linear & Log-linear & Log-linear & Log-linear & Log-linear \\
\hline $\begin{array}{l}\text { Model } \\
\text { Need variables }\end{array}$ & Fixed effect & Random effect & Fixed effect & Random effect & Fixed effect & Random effect & Fixed effect & Random effec \\
\hline $\begin{array}{l}\text { Age- and sex-standardised mortality } \\
(0-65, \text { SMR65) }\end{array}$ & 0.08 & $0.10^{*}$ & & & & & & \\
\hline $\begin{array}{l}\text { Age- and sex-standardised mortality } \\
\text { (all ages, SMR) }\end{array}$ & & & $0.41 * * *$ & $0.48 * * *$ & & & & \\
\hline $\begin{array}{l}\text { Age- and sex-standardised index of } \\
\text { disability pensions for ages } \\
15-55 \text { (DISAB) }\end{array}$ & & & & & $0.17 * * *$ & $0.18^{* * *}$ & & \\
\hline Index of migration (MIG) & & & & & $-5.92 *$ & $-5.90 * * *$ & & \\
\hline $\begin{array}{l}\text { Proportion of population living } \\
\text { alone (ALONE) }\end{array}$ & & & & & & & $0.53 * * *$ & $0.53 * * *$ \\
\hline $\begin{array}{l}\text { Proportion of households living in } \\
\text { overcrowded accommodation } \\
\text { (CROWDED) }\end{array}$ & & & $0.32 * * *$ & $0.38 * * *$ & & & & \\
\hline $\begin{array}{l}\text { Average disposable income per } \\
\text { household unit (INC) }\end{array}$ & $-0.79 * * *$ & $-0.73^{* * *}$ & & & & & $-0.55^{* * *}$ & $-0.59 * * *$ \\
\hline Hausman test & & 0.283 & & 0.161 & & 0.257 & & 0.547 \\
\hline$R^{2}$ hospital district level & 0.45 & & 0.28 & & 0.50 & & 0.24 & \\
\hline$R^{2}$ dependent variables & 0.61 & & 0.25 & & 0.41 & & 0.27 & \\
\hline$R^{2}$ total & 0.66 & & 0.36 & & 0.63 & & 0.41 & \\
\hline
\end{tabular}

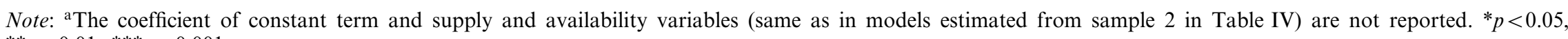
$* * p<0.01, * * * p<0.001$. 
can present each area's (municipality's) need as indices that show how the need for services in the area differs from the whole-country average.

The need indices for the service groups can be aggregated into a total need index for municipal health care and services for the elderly (NTOT):

$$
\begin{aligned}
\mathrm{NTOT}_{\mathrm{a}}= & \mathrm{W}_{\text {env }} * 1+\mathrm{W}_{\text {oph }} * \mathrm{NOPH}_{\mathrm{a}}+\mathrm{W}_{\text {other }} * \mathrm{NOTHER}_{\mathrm{a}} \\
& +\mathrm{W}_{\text {eld }} * \mathrm{NELD}_{\mathrm{a}}+\mathrm{W}_{\text {spe }} * \mathrm{NSPE}_{\mathrm{a}}+\mathrm{W}_{\text {psy }} * \mathrm{NPSY}_{\mathrm{a}}
\end{aligned}
$$

where $\mathrm{W}_{\text {env }}, \mathrm{W}_{\text {oph }}, \mathrm{W}_{\text {other }}, \mathrm{W}_{\text {eld }}, \mathrm{W}_{\text {spe }}, \mathrm{W}_{\text {psy }}$ are cost or priority weights for the six services groups $\left(\mathrm{W}_{\mathrm{env}}+\right.$ $\mathrm{W}_{\text {oph }}+\mathrm{W}_{\text {other }}+\mathrm{W}_{\text {eld }}+\mathrm{W}_{\text {spe }}+\mathrm{W}_{\mathrm{psy}}=1$ ), decided according to policy priorities.

Decisions on the amount of state subsidies can be divided into three stages, of which the first two are mainly political and the third is based on the results of this study. First, policy makers (parliament, government, and the ministry, together with municipalities) should decide the total nationwide budget for health services and care for the elderly, and how its financing is to be divided between the state and municipalities (23). Second, policy makers should choose the cost (priority) weights $(W)$ for each service group. At the third stage, the state subsidies for each municipality are then calculated as follows. First, the estimated total budget for healthcare in the whole country is divided by the population. For each municipality, the estimated total budget is then calculated by multiplying the nationwide average cost per person by its relative need indices. The final state subsidy is then obtained by reducing the municipalities' cost share of the budget from their estimated total budget.

\section{CONCLUSIONS}

We have further developed a need formula for state subsidies in Finland. Compared with capitation and risk-adjustment approaches used in other countries the range of services included is large: it covers about $70 \%$ of health services and even care of the elderly. In this study we tried to avoid some problems inherent in the old formula. First we attempted to make more explicit the role of politicians and of research in the regional allocation of resources. Politicians often discuss technical aspects such as what cost weight should be given to different age groups or what the suitable indicator for describing need for healthcare should be. Instead, their role should concentrate more on priority setting in terms of the total amount of resources to be allocated to healthcare and other public services, as well as the relative cost weights to be given to different health services. Second we developed a model based on numerous need indicators.
This reduces the effect of erroneous incentives related to indicators in the prevailing system, where need is measured by only one need indicator in addition to age.

\section{REFERENCES}

1. Rice N, Smith P. Approaches to capitation and risk adjustment in health care: an international survey. York: Centre for Health Economics, University of York, 1999.

2. Mays N. Geographical resource allocation in the English National Health Service, 1971-1994: the tension between normative and empirical approaches. Int J Epidemiol 1995; 242(3, Suppl. 1): s96-s102.

3. Coopers and Lybrand. Integrated analysis for the review of RAWP. London: Department of Geography, Queen Mary Collage and Department of General Practice, St Mary's Hospital Medical School, 1988.

4. Carr-Hill R, Hardman G, Martin S, Peacock S, Sheldon T, Smith P. A formula for distributing NHS revenues based on small area use of hospital beds. York: University of York, 1994.

5. Sheldon T, Smith P, Borowitch M, Martin S, Carr-Hill R. Attempt at deriving a formula for setting general practitioner fundholding budgets. Br Med J 1994; 309: $1059-64$.

6. Rice N, Dixon P, Lloyd D, Roberts D. Derivations of a needs based capitation formula for allocating prescribing budgets: Centre for Health Economics, University of York, 1999.

7. Arbuthnott J. Fair shares for all. Report of the National Review of resource allocation for the NHS in Scotland. Scotland: Scottish Executive Health Department, 1999.

8. Eckstein G, Gibberd RW. Relative need index for New South Wales Areas and Districts. NSW: Health Services Research Group, University of Newcastle, 1994.

9. Anderrson PA, Varde E, Diederischen F. Modelling of resource allocation to health care authorities in Stockholm County. Health Care Management Science 2000; 3(2), $141-9$.

10. Diederischen F, Varde E, Whitehead M. Resource allocation to health authorities: the quest for an equitable formula in Britain and Sweden. Br Med J 1997; 315: 875-8.

11. Häkkinen U, Mikkola $\mathrm{H}$, Nordberg $\mathbf{M}$, Salonen $\mathbf{M}$. Tutkimus kuntien terveyspalveluiden valtionosuuksien perusteista [A study on state subsidies for health care]. Helsinki: Sisäasianministeriö, 1996.

12. Hutchison B, Hurley J, Reid R, Dorland J, Birch M, Giacomini $\mathrm{M}$, et al. Capitation funding for integrated health systems: a policy synthesis. Final report submitted to the Canadian Health Services Research Foundation, Hamilton, Ontario, 1999.

13. Klavus J, Laine J. Tutkimus kuntien sosiaali- ja terveydenhuollon menoista ja olosuhdetekijöistä [Study on municipalities expenditure on health and social services and circumstances]. Helsinki: Sisäasianministeriö, 2001.

14. Häkkinen U, Luoma K. Determinants of expenditure variation in health care and care of the elderly among Finnish municipalities. Health Economics 1995; 4: $199-211$. 
15. Linna M. Measuring hospital performance: the productivity, efficiency and costs of teaching and research in Finnish hospitals. Jyväskylä: Gummerus Printing, 1999.

16. Luoma K. Terveyskeskusten tuottavuus ja panosten käytön tehokkuus 1990-luvulla [Productivity changes and efficiency in Finnish health centres in the 1990s]. Sosiaalilääketieteellinen aikakauslehti (Journal of Social Medicine) 2000; 37(3): 207-15.

17. Maddala GS. Introduction to econometrics. New York/ London: Macmillan, 1992.

18. Greene WH. Econometric analysis. Englewood Cliffs, NJ: Prentice-Hall, 1997.
19. Godfrey L, Hutton J. Discriminating between errorsin-variables/simultaneity and misspecification in linear regression models. Economics Letters 1993; 44: 359-64.

20. Rice N, Jones A. Multilevel models and health economics. Health Economics 1997; 6: 561-75.

21. Hausman JA. Specification tests in econometrics. Econometrica 1978; 46: $1251-72$.

22. Jöreskog K, Sörbom D. Lisrel 8. Hillsdale, NJ: Scientfic Software International, 1993.

23. Pekkarinen J. Kuntien peruspalvelujen rahoitus [Financing of the basic services] Helsinki: Sisäasiainministeriö, 2001.

Accepted 030409 